\title{
Impact of food and nutrition interventions on poverty in an informal settlement in the Vaal Region of South Africa
}

\author{
Wilna H. Oldewage-Theron ${ }^{1 *}$ and Tielman J. C. Slabbert ${ }^{2}$ \\ ${ }^{1}$ Vaal University of Technology, Institute of Sustainable Livelihoods, Private Bag X021, Vanderbijlpark 1900, South Africa \\ ${ }^{2}$ North-West University, Vaal Campus, PO Box 1174, Vanderbijlpark 1900, South Africa
}

\begin{abstract}
UNICEF has stated that urban poverty is primarily found in squatter settlements. At present $13.5 \%$ of all South African households live in informal settlements. The major research question is to what extent does poverty influence the food, nutrition and health of informalsettlement dwellers. The purpose of the present study was to determine the depth of poverty in this community and to measure the possible effect that planned food and nutrition interventions may have on eliminating poverty in this area. Pre-tested questionnaires were administered to 340 randomly-selected caregivers. A validated quantified FFQ was administered by trained enumerators as the test measurement for dietary intake and food consumption patterns and $24 \mathrm{~h}$ recall was used as the reference measurement, and the data were analysed. A poverty model was used to measure the impact of extra income on the poverty levels of 190 households. Of the respondents $89 \%$ lived in $\mathrm{Zn}$ shacks and the average household size was 4.9 individuals. The unemployment rate was $94.2 \%$ for respondents and $64.9 \%$ for their partners. The majority of households $(68 \cdot 8 \%$ ) had an income of $<\mathrm{R} 500$ (£35) per month and $58.3 \%$ spent $<\mathrm{R} 100$ (£6.90) per week on food. The average poverty gap was R 1342.21 (£93) and the poverty gap ratio was $56 \%$. The poverty model showed that an increase of $\mathrm{R} 500$ (£35) in monthly household income results in a poverty gap ratio of $35 \%$. The poverty model confirmed that the impact of food and nutrition interventions on poverty can be measured and that when planning these interventions the model could be used to measure their feasibility. The results indicate that this community is poverty-stricken and has chronic food insecurity, and they will be used to facilitate planning and implementation of sustainable income-generating community-based interventions to promote urban food security and alleviate poverty in this community.
\end{abstract}

Informal settlements: Socio-demographics: Malnutrition: Poverty: Household food insecurity

Despite the large number of individuals living in poverty, the debate about the definition and meaning of poverty continues $^{(1,2)}$. Poverty has a different meaning for different populations, even the poor. However, the emerging consensus is that poverty is characterised by the inability of individuals, households or communities to satisfy a socially-acceptable minimum standard of living as a result of a lack of resources ${ }^{(2)}$.

Two distinct problems have been identified in the measurement of poverty, i.e. identifying the poor in a population and developing an index of measuring poverty $^{(2)}$. A number of approaches have been followed that include first the income or expenditure approach, in which a poverty line is defined, and second consumption as a measure of poverty with 'standard of living' used as the measurement ${ }^{(1,2)}$. The general standard of living tends to be low for a large number of individuals in developing nations and is manifest in the presence of low income, poor health, limited or no education and in a general sense of hopelessness. In South Africa (SA) the poor are mainly identified as the unemployed, female-headed households and the less educated ${ }^{(3)}$.

Recent decades have shown a dramatic growth in urban poverty in developing countries, which is the case also for $\mathrm{SA}^{(3)}$. It is estimated that $>600$ million individuals live in poverty in low-income settlements in African, Asian and Latin American cities and towns ${ }^{(4)}$. UNICEF has indicated that urban poverty is primarily found in squatter 
settlements and slum areas ${ }^{(5)}$. Empirical data for this claim are, however, limited. At present, 66\% (twenty-eight million) of the population of SA are urbanised, of whom the majority have no other choice than to settle in informal settlements because of the low priority attributed to permanent housing for Africans. About $13.5 \%$ of all households in SA are forced to live in informal housing, i.e. structures that offer partial shelter against the elements. These households often have poor access to piped safe water and sanitation, which is a continuing threat to family health, specifically child survival ${ }^{(3,6-9)}$.

Health indicators, including malnutrition and household food insecurity, provide a measure of the often inadequate access of the poor to health care ${ }^{(3)}$. Health depends on the availability of good physical conditions, such as clean and plentiful water, clean air, safe and adequate food, access to sanitation, protective shelter and safe environments in which to move around ${ }^{(4)}$.

Malnutrition, specifically undernutrition, and infectious diseases are widespread in African and Asian urban centres as a result of poverty ${ }^{(4)}$. Despite the dramatic progress that has been made in some areas of nutrition in recent years, 790 million individuals in the developing world and thirtyfour million in developed countries are still undernourished and endure household food insecurity. Reducing hunger and malnutrition will continue to remain a challenge, as the International Model for Policy Analysis of Commodities and Trade estimates that malnutrition will persist in 2020 and beyond ${ }^{(10-12)}$. New information confirms an improved global nutrition situation, but the nutritional status is concurrently deteriorating in several countries, especially in Africa. Hunger and low intake of the major micronutrients remain widespread despite rapidly-declining world food prices during the past 20 years ${ }^{(11)}$.

Few studies have been done in urban households over time to understand how households establish themselves and deal with the stress as they move in and out of poverty ${ }^{(13,14)}$, suggesting that research should be conducted to investigate the micro-mechanisms influencing poverty, food and nutrition in urban communities. Issues that need to be addressed include: food sources and costs; income; urban agriculture; urban diets; health; childhood mortality; morbidity and malnutrition; child caregiving practices; food insecurity. Studies have shown that the control of resources ${ }^{(15)}$ and intra-household relationships ${ }^{(16)}$ usually determine whether households are food secure.

The focus of the present research project was on poverty, malnutrition and household food insecurity in an informal settlement in the Vaal Region of SA. The Vaal Region is an industrial area situated approximately $70 \mathrm{~km}$ south of Johannesburg and has a population of 794599, of which $48 \%$ are unemployed and $46 \%$ of households live in poverty ${ }^{(17)}$. The purpose of the present study was to determine the depth of poverty in this community and to measure, by means of a poverty model ${ }^{(18)}$, the possible effect that planned interventions might have on eliminating poverty in the area. The results of this assessment will ultimately assist in formulating policies to reduce poverty, diseases, malnutrition and illiteracy and to accelerate urban development, and thus contribute to the national health plan that aims to improve the healthcare system for all South Africans.

\section{Methods employed for the baseline survey}

This survey comprised an integrated nutrition research project in which socio-demographic and dietary intake variables were investigated in 340 randomly-selected households $(27 \%$ of the total households in the informal settlement). The Ethics Committee of the Vaal University of Technology approved the study. The protocol was submitted in accordance with the existing policy for research in the institution.

The measurement procedures included a pre-tested socio-demographic and health questionnaire and a validated quantified $\mathrm{FFQ}^{(19)}$. In order to verify dietary intake, all subjects completed the quantified FFQ in individual interviews with the assistance of trained field workers. Food models were used simultaneously to determine portion sizes and to explain food items to the subjects. A 24 h-recall questionnaire served as a reference measure for the quantified FFQ. A total of 409 quantified FFQ and $24 \mathrm{~h}$-recall questionnaires were completed, as all the female caregivers (mothers, grandmothers, guardians) in the household were included.

A questionnaire to determine specific poverty indicators, e.g. literacy levels, unemployment and actual income, was compiled and tested for reliability in ten households, and subsequently administered to a random sample of 429 households (34\%) with both male and female caregivers in this informal settlement of 1261 households.

Data analysis of the socio-demographic questionnaires was done using the Statistical Package for Social Sciences for Windows version 10.0 (SPSS Inc., Chicago, IL, USA). Descriptive statistics (frequencies, means, standard deviations and confidence intervals) were determined. The dietary intake and food consumption data were analysed by a registered dietitian using the FoodFinder ${ }^{\circledR}$ program (Medical Research Council of South Africa, Cape Town, South Africa), based on the SA food composition tables ${ }^{(20)}$. Means and standard deviations were calculated for food and nutrient intake and various correlations were investigated.

The data for the poverty indicators were transferred to a Microsoft Excel ${ }^{\circledR}$ spreadsheet and analysed for descriptive statistics. The poverty model (see p. 94) was then applied to measure the depth of poverty in this community and the possible impact of income-generating activities.

\section{Demographic profile of the informal-settlement dwellers}

The baseline survey results showed that $89.9 \%$ of all these households in this informal settlement lived in nonpermanent-structure $\mathrm{Zn}$ shacks and $88.8 \%$ of all the respondents had lived this way for $>5$ years. The houses were small and only $26.3 \%$ of all the households had four or more rooms; however, these houses accommodated an average of 4.9 individuals. Problems such as rodent 
infestation $(53.2 \%)$, dampness $(30.8 \%)$, cold $(9.8 \%)$ and rust $(6.7 \%)$ were experienced permanently.

The education level of the respondents indicated widespread illiteracy, as a large percentage only attended primary school $(48.5 \%)$ or had no education $(23 \cdot 2 \%)$. Furthermore, only $5.8 \%$ of the respondents and $19.9 \%$ of their spouses were employed. The majority of the respondents indicated that they had been without a job for $>3$ years $(59 \cdot 1 \%)$, although the minority $(10 \cdot 1 \%)$ was of retirement age ( $\geq 60$ years old). The majority of households $(58.3 \%)$ had an income of $<\mathrm{R} 1000$ (£69) per month. All these factors indicate the prevalence of poverty in this community.

Household food insecurity was another problem identified in this community. Most of the respondents (61.6\%) indicated that they procured food once monthly, mainly from the local 'spaza' or tuck shop in the area $(55.5 \%)$. As $58.3 \%$ of households spent $<\mathrm{R} 100(£ 6.90)$ per week on food and the average household size was 4.9 individuals, each household could only spend R $2.90(£ 0 \cdot 20)$ per individual per $\mathrm{d}$ on food, i.e. equivalent to two-thirds of one loaf of bread or 0.5 litre milk. In most instances, the mother was responsible for the food procurement decisions $(83.8 \%)$, food preparation $(81.8 \%)$ and feeding the children $(79 \cdot 6 \%)$. It may be concluded therefore that with this limited amount of money available for food purchases, malnutrition may be present in this sample.

The health status of the respondents was also compromised. Although the consumption of cigarettes $(15 \cdot 2 \%)$ and alcohol $(27 \cdot 3 \%)$ was not very high amongst the respondents, they were subjected to high levels of pollution; environmentally this area has the highest level of pollution in the country because of the local industry (steel-production plants and plants processing coal into petrol, chemicals and a variety of petrochemicals). Furthermore, the waste-removal service was almost nonexistent and the area was very dusty; most of the respondents only had use of gravel roads $(88.2 \%)$. Although all respondents had access to clean safe water and toilet facilities, electricity was expensive and most did not have the money to buy electricity. Most of the food was prepared on coal stoves that were also expensive to use and contributed significantly to pollution.

Although the majority of households made use of the mobile clinic $(74.9 \%)$ for preventative and curative medical care, this facility was only available on $3 \mathrm{~d}$ per week. The nearest hospital was $5 \mathrm{~km}$ from the informal settlement and the majority of respondents walked to the health facilities $(79.7 \%)$ because of a lack of money to pay for public transport. The most prevalent diseases in this area were chronic coughing (42\%) and headaches $(50 \cdot 4 \%)$. Antenatal care seemed to be a problem, as $27.7 \%$ of all households had experienced the death of one child aged $<5$ years during the previous 5 years. Of these deaths, $34.8 \%$ were stillbirths, which indicated poor maternal health.

\section{Dietary intake and food consumption patterns}

The nutrient intakes of the respondents are shown in Table 1. Although the majority of households indicated
Table 1. Mean daily intakes of the female caregivers in the household ( $n 409$ ) measured by quantified FFQ and $24 \mathrm{~h}$ recall

\begin{tabular}{|c|c|c|c|c|c|}
\hline \multirow[b]{2}{*}{ Nutrient } & \multicolumn{2}{|c|}{ Quantified FFQ } & \multicolumn{2}{|c|}{$24 \mathrm{~h}$ recall } & \multirow[b]{2}{*}{$\mathrm{EAR}^{*}$} \\
\hline & Mean & SD & Mean & SD & \\
\hline Energy (kJ) & 3840 & 430 & 4550 & 993 & 10093 \\
\hline Total protein (g) & $24 \cdot 5$ & $22 \cdot 7$ & $19 \cdot 7$ & $9 \cdot 3$ & 46 \\
\hline Total fat (g) & $26 \cdot 9$ & $31 \cdot 4$ & $20 \cdot 9$ & $20 \cdot 8$ & \\
\hline Cholesterol (mg) & $84 \cdot 8$ & 116 & $55 \cdot 8$ & 118 & \\
\hline Carbohydrates (g) & 135 & $94 \cdot 6$ & 182 & $77 \cdot 9$ & 100 \\
\hline $\mathrm{Ca}(\mathrm{mg})$ & 116 & 165 & 150 & 177 & 580 \\
\hline $\mathrm{Fe}(\mathrm{mg})$ & 3.54 & $4 \cdot 73$ & 3.79 & $2 \cdot 04$ & $8 \cdot 1$ \\
\hline $\mathrm{Mg}(\mathrm{mg})$ & 136 & 103 & 195 & $93 \cdot 5$ & 265 \\
\hline $\mathrm{Zn}(\mathrm{mg})$ & $2 \cdot 9$ & $2 \cdot 7$ & $3 \cdot 8$ & $2 \cdot 4$ & $6 \cdot 8$ \\
\hline $\mathrm{Cu}(\mathrm{mg})$ & 0.39 & 0.42 & 0.41 & $0 \cdot 29$ & \\
\hline $\operatorname{Cr}(\mu \mathrm{g})$ & $14 \cdot 3$ & $23 \cdot 3$ & $14 \cdot 7$ & $19 \cdot 8$ & \\
\hline $\mathrm{Se}(\mu \mathrm{g})$ & $10 \cdot 3$ & $16 \cdot 6$ & $8 \cdot 27$ & $13 \cdot 2$ & 45 \\
\hline I $(\mu \mathrm{g})$ & $11 \cdot 3$ & $16 \cdot 3$ & 8.97 & $18 \cdot 1$ & 95 \\
\hline Vitamin A (RE; $\mu \mathrm{g})$ & 211 & 453 & 176 & 617 & 500 \\
\hline Thiamin (mg) & $0 \cdot 6$ & 0.51 & 0.72 & 0.32 & 0.9 \\
\hline Riboflavin (mg) & 0.32 & 0.51 & 0.35 & 0.36 & 0.9 \\
\hline Niacin (mg) & $4 \cdot 58$ & $6 \cdot 66$ & 4.93 & $4 \cdot 08$ & 11 \\
\hline Vitamin $B_{6}(\mathrm{mg})$ & 0.30 & 0.50 & 0.34 & 0.23 & $1 \cdot 1$ \\
\hline Folate $(\mu \mathrm{g})$ & $64 \cdot 2$ & $87 \cdot 6$ & $85 \cdot 1$ & 125 & 320 \\
\hline Vitamin $B_{12}(\mu \mathrm{g})$ & $1 \cdot 33$ & $2 \cdot 76$ & $1 \cdot 19$ & $3 \cdot 17$ & $2 \cdot 0$ \\
\hline Pantothenate (mg) & $1 \cdot 67$ & $2 \cdot 19$ & $1 \cdot 78$ & $1 \cdot 65$ & \\
\hline Biotin $(\mu \mathrm{g})$ & $10 \cdot 5$ & $10 \cdot 4$ & $14 \cdot 6$ & $25 \cdot 3$ & \\
\hline Vitamin C (mg) & $13 \cdot 4$ & $25 \cdot 7$ & $14 \cdot 3$ & $14 \cdot 9$ & 60 \\
\hline Vitamin D $(\mu \mathrm{g})$ & $1 \cdot 45$ & $2 \cdot 09$ & 0.73 & $1 \cdot 84$ & \\
\hline Vitamin E (mg) & $7 \cdot 42$ & $10 \cdot 4$ & $4 \cdot 56$ & $7 \cdot 33$ & 12 \\
\hline
\end{tabular}

$\mathrm{RE}$, retinol equivalents; EAR, estimated average requirement. ${ }^{*}$ For females aged $19-50$ years ${ }^{(29)}$.

that they ate two $(57.8 \%)$ or three $(23.5 \%)$ meals daily, nutrient analysis by both the quantified FFQ and $24 \mathrm{~h}$ recall indicated that carbohydrate was the only nutrient meeting the estimated average requirements. This pattern was further illustrated by the twenty food items most frequently consumed, which indicated that maize-meal porridge was the only food item consumed by $100 \%$ of the households on a regular basis. The ten most-frequently-consumed items according to the quantified FFQ analysis were (mean daily consumption) stiff maize-meal porridge $(345 \mathrm{~g})$, soft maize-meal porridge $(124 \mathrm{~g})$, brewed rooibos tea $(80 \mathrm{ml})$, brewed tea $(79 \mathrm{ml})$, brewed coffee $(76 \mathrm{ml})$, sorghum porridge $(74 \mathrm{~g})$, white bread $(73 \mathrm{~g})$, crumbly maize porridge $(63 \mathrm{~g})$, carbonated cold drink $(52 \mathrm{ml})$ and mageu (a commercial sorghum drink; $51 \mathrm{~g}$ ). The only protein sources included in the top-twenty list were soyabeans (11th) and chicken and vegetable stew (13th), with mean daily intakes of $51 \mathrm{~g}$ and $45 \mathrm{~g}$ respectively. A minority of respondents consumed these two protein sources (nineteen and twentyfive respondents respectively). The majority of food items appearing on the top-twenty food list were carbohydrates, indicating a carbohydrate-based diet.

In Tables 2 and 3 only the significant correlations $(P \leq 0.05)$ are reported. Table 2 shows that those female caregivers who were employed could afford to buy more fresh fruit, vegetables, butter or margarine, chicken and tripe. The fat and energy intakes of mothers who were 
Table 2. Variables showing a correlation $(P \leq 0.05)$ with the caregiver's employment status

\begin{tabular}{lcc}
\hline Variable & $P$ & Statistical method \\
\hline Energy intake & 0.054 & Tamhane \\
Fat intake & 0.026 & Tamhane \\
Weekly child allowance & 0.039 & $\chi^{2}$ \\
Frequency of food shopping & 0.030 & $\chi^{2}$ \\
Where food is purchased & 0.001 & $\chi^{2}$ \\
Chicken purchases & 0.043 & $\chi^{2}$ \\
Tripe purchases & $>0.001$ & $\chi^{2}$ \\
Butter or margarine purchases & 0.043 & $\chi^{2}$ \\
Fresh fruit purchases & 0.041 & $\chi^{2}$ \\
Fresh vegetable purchases & 0.002 & $\chi^{2}$ \\
\hline
\end{tabular}

employed were significantly higher than those of mothers who were not employed $(P=0.026$ and $P=0.054$ respectively), which could be the result of food being brought into the household more frequently. This notion was confirmed by the results that indicated that caregivers who were employed bought food more often and also at more affordable suppliers such as supermarkets $v$. the tuck shops in the informal settlement.

The results in Table 3 indicate that the caregivers with a higher education level had a significantly higher intake of Fe $(P=0 \cdot 077)$, energy $(P=0 \cdot 032)$, protein $(P=0 \cdot 078)$ and carbohydrate $(P=0.021)$, as well as a significantly lower number of children in the household $(P=0 \cdot 016)$. Egg and milk purchases were significantly higher $(P=0.090$ and $P=0.007$ respectively) than those of mothers with a lower education.

\section{Unemployment}

Statistics South Africa uses the following definition of unemployment as its official definition, 'the unemployed are those people within the economically active population who: (a) did not work during the seven days prior to the interview; (b) want to work and are available to start within a week of the interview; (c) have taken active steps to look for work or to start some form of self-employment in the four weeks prior to the interview ${ }^{\prime(21)}$.

These general criteria are translated into statistically meaningful criteria: the population of potential working age (i.e. $\geq 15$ years); the economically non-active (i.e. those who prefer not to or who cannot work, e.g. housewives, individuals $>65$ years old, the disabled); the economically-active population (all those who are fit to work, wish to work, have no employment and are ready for and actively looking for work, plus the employed and self-employed).

The unemployment rate (Ur) is calculated according to the standard equation:

$$
\mathrm{Ur}=\frac{\text { no. of unemployed }}{\text { economically-active population }} \times 100 \text {. }
$$

In developed countries this definition is relatively simple to apply. The criteria for measuring unemployment are
Table 3. Variables showing a correlation $(P \leq 0.05$ or $P \leq 0.10)$ with the caregiver's education status

\begin{tabular}{llc}
\hline Variable & \multicolumn{1}{c}{$P^{\star}$} & Statistical method \\
\hline Energy intake & 0.030 & Bonferroni \\
Protein intake & $0.078 \dagger$ & Bonferroni \\
Carbohydrate intake & 0.021 & Bonferroni \\
Child immunisation & 0.058 & $\chi^{2}$ \\
Egg purchases & $0.090 \dagger$ & $\chi^{2}$ \\
Milk purchases & 0.007 & $\chi^{2}$ \\
No. of children in the household & 0.016 & ANOVA \\
\hline
\end{tabular}

${ }^{*} P \leq 0.05$, except where indicated.

†Significant at $90 \%$ confidence level $(P \leq 0 \cdot 10)$.

straight and definite, i.e. an individual is out of work and is actively looking for a job by means of a listing at a placement or other government office. However, in developing countries circumstances are very different, and it is not always clear whether or not an individual is seeking employment. In SA some unemployed individuals become discouraged and therefore refrain from taking active steps to seek employment.

In the present survey only one criterion was taken as an indication of seeking work, i.e. if an individual 'has the desire to work and to take up employment or selfemployment'. The question asked was simply 'do you want to work'. When the standard Statistics South Africa definition $^{(21)}$ is used, but its strict criteria are relaxed, as was done in the present survey, it is referred to as an expanded definition of unemployment, which includes criteria (a) and (b), but not (c) ${ }^{(3)}$.

Statistics South Africa's definition for employment, which defines 'employed' as 'those who performed work for pay, profit or family gain in the seven days prior to the household survey interview, or who were absent from work during these seven days, but had some form of paid work to which they can return, ${ }^{(3)}$ was also simplified. The question asked was simply 'do you work for a business, for yourself or for your family'. Working for a business was regarded as formal employment. Self-employment and family employment were taken as working in the informal sector ${ }^{(22)}$. According to this definition the Ur for the respondents in this informal settlement was $90 \cdot 5 \%$.

\section{Poverty in the informal settlement}

Following the World Bank guidelines ${ }^{(23)}$ a poor household is defined as a household of which the combined income of all its members is less than the household subsistence level as determined for the specific household. If the combined income of a household is described by $\mathrm{y}_{\mathrm{i}}$ and the poverty line (household subsistence level) of the same household is described by $z_{i}$, the extent of poverty, $P_{i}$, of this household is described by $\mathrm{P}_{\mathrm{i}}\left(\mathrm{y}_{\mathrm{i}} ; \mathrm{z}_{\mathrm{i}}\right)$.

To measure (and map) poverty in SA, Statistics South Africa use household income (or expenditure) data 
obtained from the 1996 and 2001 censuses and a standard poverty line ${ }^{(24,25)}$. The income of households is calculated by adding together the individual incomes (proxy value) of all members of the household. This result is then reallocated into a relevant income category, as individual incomes were recorded in intervals and not in exact amounts in both the 1996 and 2001 censuses. In order to compare the income of a household with the poverty line, the proxy values of the category in which the household falls is taken as the income of the household. This income is then compared with the poverty line in order to determine whether the household is poor or not; where the income is less than the poverty line, the household is considered poor. Applying this methodology to census data on a countrywide scale for the mapping of poverty ${ }^{(24)}$ may give reasonable results. However, applying this methodology at a micro level for the analysis of poverty in a specific township (SA's second economy) gives inaccurate results. Households with a relatively-high combined income can easily be classified non-poor, while in reality the household may be poor because of a great number of dependants. A small household with a relatively low income may on the other hand be classified as poor, while in actual fact it may not be poor, because of the few dependants in the household. A standard poverty line compared with mid-point estimates of income is totally insensitive for this situation. A far more accurate methodology is to compare the actual income of each household with a poverty line that is calculated for the specific household, based on the number of members, their ages and gender.

A methodology has been developed for this purpose ${ }^{(18)}$, making use of the household subsistence level as defined by Potgieter ${ }^{(26)}$. Based on the data collected at the household level, the household subsistence level can be determined for a specific household. If the combined income of a household is described by $y_{i}$ and the poverty line (household subsistence level) of the same household is described by $z_{i}$, the extent of poverty, $P_{i}$, of this household is described by $\mathrm{P}_{\mathrm{i}}\left(\mathrm{y}_{\mathrm{i}} ; \mathrm{z}_{\mathrm{i}}\right)$.

The head count index is then defined as the proportion of the population below the poverty line. In the present article the head count index has been adapted to indicate the proportion of households that fall below their individual poverty lines, and is described by the equation:

$$
\mathrm{H}(\mathrm{y} ; \mathrm{z})=\mathrm{M} / \mathrm{N}
$$

where $\mathrm{H}$ is the proportion of households below the poverty line, $\mathrm{y}$ is household income, $\mathrm{z}$ is the poverty line of households, $M$ is the number of households with incomes $<\mathrm{Z}$ and $\mathrm{N}$ is the total number of households.

Of a sample of 429 households (34\% of the community population) in the informal settlement, $44 \%$ ( $n$ 286) were earning incomes below their respective poverty lines, giving a head count index of $0 \cdot 67$, indicating that $67 \%$ of the households are living in poverty.

The poverty gap usually measures the average shortfall of the incomes of the poor from the poverty line, while the poverty gap index measures the extent of the shortfall of incomes below the poverty line. In the present report the poverty gap index has been adapted to be a measure of a specific household, described by the equation:

$$
\mathrm{R}_{\mathrm{i}}(\mathrm{y} ; \mathrm{z})=\left(\mathrm{z}_{\mathrm{i}}-\mathrm{y}_{\mathrm{i}}\right) / \mathrm{z}_{\mathrm{i}},
$$

where $R_{i}$ is the income shortfall of a household expressed as a proportion of the household's poverty line, $y_{i}$ is the income of a specific household and $z_{i}$ is the poverty line of a specific household.

The poverty gap index for households in the informal settlement was $0 \cdot 56$, implying that households on average have a shortfall of $77 \%$ of the income required to maintain a level equal to their poverty lines.

The poverty gap of an individual household (in monetary terms) can therefore be expressed by the equation:

$$
\mathrm{G}_{\mathrm{i}}(\mathrm{y} ; \mathrm{z})=\mathrm{z}_{\mathrm{i}}-\mathrm{y}_{\mathrm{i}} \text {, }
$$

where $G_{i}$ is the income shortfall of a household, $y_{i}$ is the income of a specific household and $z_{i}$ is the poverty line of a specific household.

From these three equations it is clear that the poverty gap can only be reduced by increasing household income.

The average amount of the poverty gap in the informal settlement was R 1017 (£70·10), indicating the average shortfall of income to maintain a level equal to the poverty line ${ }^{(18)}$.

\section{The impact of some proposed projects on poverty and unemployment}

Employment creation, food gardens and public work programmes may supplement the existing income of households to such an extent that the head count index for the population is decreased significantly. If the number of unemployed individuals in a household is described by $\mathrm{u}_{i}$, and they can earn an income through projects (e.g. food gardens) at an average monetary value of $\mathrm{W}$, the poverty gap $\mathrm{G}_{\mathrm{i}}$ of a single household can be reduced by:

$$
\mathrm{G}_{\mathrm{i}}-\left(\mathrm{u}_{\mathrm{i}} \mathrm{W}\right),
$$

or

$$
\mathrm{z}_{\mathrm{i}}-\left(\mathrm{y}_{\mathrm{i}}+\mathrm{u}_{\mathrm{i}} \mathrm{W}\right),
$$

where $u_{i}$ is the number of unemployed members in a household and $\mathrm{W}$ is the average wage earned by unemployed members of households as a result of an employment creation scheme.

A project (e.g. vegetable garden project) aimed at the unemployed poor will have an immediate effect on the extent of poverty, because it reduces the poverty gap. However, to have a significant effect, it should reduce the head count index. The extent to which the head count index is reduced will indicate the success of an employment creation programme. The condition for reducing the head count index is that the poverty gap of a household or households becomes zero or negative. This condition is 
described by the following equation:

$$
\mathrm{G}_{\mathrm{i}}-\left(\mathrm{u}_{\mathrm{i}} \mathrm{W}\right) \leq 0,
$$

where $G_{i}$ is the poverty gap of a single household, $u_{i}$ is the number of unemployed members in a household and $\mathrm{W}$ is the average wage earned by unemployed members of households as a result of an employment creation scheme. The larger the number of households satisfying this condition, the smaller the head count index becomes.

The survey data of this informal settlement were used for determining the impact of food gardens on poverty in the area. The data rendered all the information needed to test these models, e.g. the age and gender of household members required to determine the individual poverty line (z) for each individual household, the combined income of each individual household (y) and the number of unemployed members in a household $(\mathrm{u})^{(18)}$.

In addition to improving micronutrient intake and thus immunity against disease, a vegetable garden project that will provide households on average with food with a monetary value of R 300 (£20.70) per month will have the following impact: the head count index will drop from 0.67 to 0.59 ; the poverty gap ratio will drop from 0.56 to 0.43 ; the average poverty gap will drop from R $1017(£ 70 \cdot 10)$ to R821 (£56.60) per month.

If, in addition to the vegetable gardens, unemployed individuals could be involved in projects that will provide them with an monthly income of only R200 (£13.80), the head count index will drop to 0.50 and the poverty gap index from 0.56 to 0.35 , indicating that these two kinds of projects will have a major impact on the depth of poverty in the informal settlement. Respondents will now be able to procure not only two-thirds of one loaf of bread or 0.5 litre milk as indicated earlier, but will be able to afford other more expensive ingredients such as protein sources to contribute to a more-balanced diet.

\section{Conclusion and recommendations}

The findings of the present study confirm that poverty, malnutrition and chronic household food insecurity, possibly resulting in poor health, are the major problems in this urban informal settlement community. The underlying causes of malnutrition are poverty, household food insecurity, inadequate care for the vulnerable groups such as mothers and children, insufficient essential human services including health, education, water and environmental sanitation and housing ${ }^{(27)}$. Many of these factors were present in the current study, i.e. household food security, uncollected household waste and pest infestations indicating poor environmental sanitation and small and insecure $\mathrm{Zn}$ houses. Furthermore, of a sample of 429 households in the informal settlement, 67\% ( $n$ 286) of these households were earning incomes below their respective poverty lines, giving a head count index of 0.67 and indicating that $67 \%$ of the households were living in poverty. These data were further confirmed by the income levels and living conditions found in this community. These adverse conditions usually contribute to disease in children and cause illness in adults ${ }^{(28)}$. The standard of living for individuals living in developing countries is manifest in the presence of low income, poor health, limited or no education and a general sense of hopelessness ${ }^{(3)}$. When these criteria are applied to this community, it can be concluded that they have a low standard of living and therefore food aid or incomegenerating activities should be implemented to assist these households.

Measuring the impact of food and nutrition interventions on poverty is a relatively new concept in food and nutrition research. The present study has confirmed that the impact of agricultural interventions on poverty in a household can be measured by the poverty model, and these interventions can have an effect on poverty in a community. It is, however, important to look at subjects holistically and to determine the impact of interventions not only on household food insecurity and malnutrition but also on poverty, as poverty and income levels influence food procurement patterns and thus household food insecurity and malnutrition. A limitation of the present study is that the input costs of the agricultural intervention were not taken into consideration when measuring the impact on poverty, but this model could still provide valuable information, when planning food and nutrition interventions, to determine the feasibility of these interventions before implementation.

The results of the present study will be used to plan and implement sustainable community-based intervention projects to alleviate poverty and thus promote public health nutrition in the Vaal Region. The focus of all intervention studies should be to reduce urban poverty, malnutrition and household food insecurity. Simultaneous health-promotion programmes that aim to provide skills and improve knowledge should be implemented to support the effectiveness and sustainability of the community-based interventions. These programmes should be focused on the female caregiver, as she is responsible for most of the important functions in the household. The results show that the caregivers with a higher education have a significantly higher intake of the macronutrients and $\mathrm{Fe}$, compared with those with a lower education. The caregivers with a better education also have more children with complete immunisation records, indicating that knowledge contributes to better practices. Creating awareness of good health and hygiene practices through health- and nutrition-promotion programmes should thus equip the female caregivers with the knowledge and skills necessary for making better food choices. Women may benefit from the knowledge of health practices in an underprivileged area and may in turn improve the quality of life in their community by means of enhancement of early child care and education opportunities.

\section{Acknowledgements}

We acknowledge the following for their cooperation in the project so far: the Departments of Education and Health in the Vaal Region, the Sedibeng District Council, the Vaal University of Technology and National Research Foundation for funding this project, as well as the informal settlement community. We furthermore want to acknowledge 
Michelle Wright (research assistant) and Verena Nolan (statistician) for their valuable assistance, as well as Carin Napier, Emsie Dicks, Rajab Rutengwe and the field workers who assisted with the data collection.

\section{References}

1. Bhorat H, Leibbrandt M, Maziya, M, van der Berg S \& Woolard I (2001) Fighting Poverty: Labour Markets and Inequality in South Africa. Cape Town: Mills Litho.

2. Ngwane A, Yadavalli V \& Steffens F (2001) Poverty in South Africa - a statistical analysis. Dev South Afr 18, 201215.

3. Motloung B \& Mears R (2002) Combating poverty in South Africa. Dev South Afr 19, 531-543.

4. Stephens C (2000) Threats to urban health. In Achieving Urban Food and Nutrition Security in the Developing World. International Food Policy Research Institute 2020 Focus no. 03, Brief no. 09 [James L. Garrett and Marie T. Ruel, editors]. Washington, DC: IFPRI; available at http://www. ifpri.org/2020/focus/focus03/focus03_09.asp

5. UNICEF (1998) The State of the World's Children. New York: UNICEF.

6. Arendse R (1992) Environmental health related intervention in Imizamu Yethu, an informal settlement in Hout Bay. Urbanisation Health Newsl 15, 53-55.

7. Cunnan P \& Maharaj B (2000) Against the odds: health care in an informal settlement in Durban. Dev South Africa 17, 667-686.

8. Mabin A (1988) Households: history and black urbanisation: response to Graaff. Dev South Afr 5, 393-402.

9. Mathee A \& Von Schirnding YER (1995) A study of the environmental health status, living conditions and basic needs of an informal settlement community in the Cape Peninsula. South Afr J Epidemiol Infect 10, 8-11.

10. Flores R (2001) Overview. In Health and Nutrition: Emerging and remerging issues in developing countries. International Food Policy Research Institute 2020 Focus no. 5. Brief no. 1 [R Flores and S Gillespie, editors]. Washington, DC: IFPRI; available at http://www.ifpri.org/2020/focus/ focus05/focus05_01.asp

11. Pinstrup-Andersen P \& Babinard J (2001) Globalisation and human nutrition: opportunities and risks for the poor in developing countries. Afr J Food Nutr Sci 1, 9-8.

12. Underwood BA (2001) Global nutrition agenda: the role of IUNS. Afr J Food Nutr Sci 1, 53-55.

13. Haddad L, Ruel MT \& Garrett JL (1999) Are urban poverty and undernutrition growing? Some newly assembled evidence. International Food Policy Research Institute Food Consumption and Nutrition Division Discussion Paper no. 63, pp. 1-2. Washington, DC: IFPRI; available at http:// www.ifpri.org/divs/fcnd/dp/papers/dp63.pdf
14. Ruel MT, Garrett JL, Morris SS, Maxwell D, Oshaug A, Engle P, Menon P, Slack A \& Haddad L (1998) Urban challenges to food and nutrition security: a review of food security, health and caregiving in the cities. International Food Policy Research Institute Food Consumption and Nutrition Division Discussion Paper no. 51, pp. 1-2. Washington, DC: IFPRI; available at http://www.ifpri.org/ divs/fend/dp/papers/dp51.pdf

15. Mancusi-Materi E (2000) Working for sustainable livelihoods and food security: voices from the grassroots. Development 43, 85-93.

16. Lemke S (2001) Food and nutrition security in black South African households - creative ways of coping and survival. $\mathrm{PhD}$ Thesis, Potchefstroom University for Christian Higher Education, South Africa.

17. McIlrath L \& Slabbert T (2003) Sedibeng Economic Regeneration Summit. Vanderbijlpark, South Africa: Emfuleni Local Government.

18. Slabbert TJC (1997) Poverty amongst black households in the Vaal Triangle Metropolitan Area: a micro-analysis. PhD Thesis. Vista University, Vanderbijlpark, South Africa.

19. MacIntyre U (1998) Dietary intakes of Africans in transition in the North West Province. PhD Thesis. Potchefstroom University for Christian Higher Education, Potchefstroom, South Africa.

20. Langenhoven M, Kruger M, Gouws E \& Faber M (1991) MRC Food Composition Tables, 3rd ed. Parow, South Africa: South African Medical Research Council.

21. Statistics South Africa (2000) October Household Survey 1999. Statistical Release P0137. Pretoria, South Africa: Government Printer.

22. Slabbert TJC \& Slabbert G (2002) Emfuleni Municipal Area (EMA): Urban Economic Review and Projection of Local Economic Sustainability. Research Report no 10, Vanderbijlpark, South Africa: Vaal Research Group.

23. World Bank (1990) Poverty. Washington, DC: Oxford University Press.

24. Statistics South Africa (2000) Measuring Poverty in South Africa. Pretoria, South Africa: SSA.

25. Statistics South Africa (2003) Methodology for Measuring Poverty in South Africa. Pretoria, South Africa: SSA.

26. Potgieter JF (1980) Background and Interpretation of the Household Subsistence Level. Port Elizabeth, South Africa: Institute for Planning Research.

27. Food and Agriculture Organization (1998) The Right to Food in Theory and Practice. Rome: FAO.

28. International Food Policy Research Institute (2002) Living in the City. Challenges and Options for the Urban Poor. Washington, DC: IFPRI; available at http://www.ifpri.org/ pubs/ib/ib9.pdf

29. Institute of Medicine, Food and Nutrition Board (2003) Dietary Reference Intakes. Washington, DC: National Academies Press. 